\title{
Antioxidant Activities of Ethanolic and Aqueous Extracts of Asparagus racemosus Roots
}

\author{
Ladachart Taepongsorat ${ }^{1, *}$, Surapong Rattana ${ }^{2,3}$
}

\section{Ladachart Taepongsorat ${ }^{1, *}$, Surapong Rattana ${ }^{2,3}$ ${ }^{1}$ Faculty of Medicine, Mahasarakham University, Mahasarakham 44000, THAILAND. \\ 2Pharmaceutical Chemistry and Natural Products Research Unit, Faculty of Pharmacy, Mahasarakham University, Mahasarakham 44150, THAILAND. ${ }^{3}$ Division of Science Education, Fac- ulty of Education, Nakhon Phanom University, Nakhon Phanom 48000, THAILAND.}

\section{Correspondence:}

Ladachart Taepongsorat Faculty of Medicine, Mahasarakham University, Mahasarakham 44000, THAILAND.

Phone no: +66 43754121

E-mail: ladachart20@yahoo.com History

- Submission Date: 11-04-2018;

- Review completed: 16-05-2018;

- Accepted Date: 11-07-2018.

DOI : 10.5530/pj.2018.6.192

Article Available online http://www.phcogj.com/v10/i6

\section{Copyright}

(C) 2018 Phcog.Net.This is an open-access article distributed under the terms of the Creative Commons Attribution 4.0 International license.

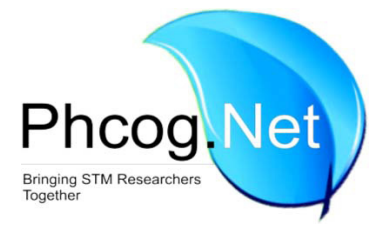

\begin{abstract}
Background: Asparagus racemosus (AR) is commonly known as shatavari, satawar or satmuli in India and in Thailand it is call sam-sib or rak-sam-sib. The dried root of AR is used in Ayurveda as an antiulcerous and antiinflammatory and has medicinal/pharmacological value. Objective: To investigate the antioxidant activities of Asparagus racemosus root extracts via total phenolic and total flavonoid contents of ethanolic and aqueous extracts. Methods: Antioxidant capacity measurements were carried out by DPPH, ABTS and FRAP methods. Total phenolic and flavonoid contents were determined by the Folin-Ciocalteu method and the aluminum chloride colorimetric method, respectively. Results: The ethanolic extract possessed higher antioxidant capacities than the aqueous extract in the three antioxidant assays $(p<0.05)$. These results have shown high phenolic and flavonoid contents. The ethanolic extract of AR root possessed higher amounts of phenolic and flavonoid contents than the aqueous extract. Conclusion: The antioxidant capacity of the ethanolic extract was higher than that in the aqueous extract.
\end{abstract}

Key words: Asparagus racemosus, Antioxidant activity, Phenolic compound, Flavonoid.

\section{INTRODUCTION}

Asparagus racemosus (AR) wild., (Family: Liliaceae), commonly known as shatavari, satawar or satmuli, is found in all over India, and is commonly known in Thailand as sam-sib or rak-sam-sib. In Ayurveda, the dried root of AR is used as a tonic, galactogogue, aphrodisiac, rejuvenator, antispasmodic, antiulcerous and anti-inflammatory agent. Steroidal saponins and sapogeninsare the pharmacological value of the AR root. ${ }^{1-2}$ Antioxytocic activities, antihepatotoxic, hepatopathy, dyspepsia and dysentery are the uses of the root of AR for treatment. ${ }^{1}$ Recent reports on AR indicate that the root extracts show antioxidant and antidiarrheal activities in animal models. ${ }^{3-4}$

Phytoanalysis of the AR root composition by Visavadiya et al..$^{5}$ found phytosterols $0.79 \%$, saponins $8.83 \%$, polyphenols $1.69 \%$, flavonoids $0.47 \%$ and total ascorbic acid $0.76 \%$. AR contains alkaloids, flavonoids, tannins, saponins, phenols, terpenes, polysaccharides and steroids. ${ }^{5}$ AR root extract was found to contain flavonoids, polyphenols and vitamin $\mathrm{C}$, which were found to exhibit the greatest antioxidant activity. A phytoestrogenic effect of AR root extracts has recently been found as well as antidiarrhoeal, antidyspepsia, adaptogenic, cardioprotective, antibacterial, immune adjuvant and antitussive effects. The methanolic and aqueous extracts of AR roots have been produced in tablet form, root powder in tablet form and root extract in syrup form. ${ }^{6}$

The objective of this research is to determine the antioxidant properties of ethanolic and aqueous extracts of the roots of AR. The ethanolic and aqueous extracts were investigated for the antioxidant properties, including DPPH, ABTS, FRAP, total flavonoid and total phenol.

\section{MATERIALS AND METHODS}

\section{Plant Material}

The plant samples (roots) of AR were collected from Khonkaen province, Thailand and identified by the authors. The voucher specimens were deposited at the Pharmaceutical Chemistry and Natural Product Research Unit, Faculty of Pharmacy, Mahasarakham University, Thailand (MSU.PH-LIL-AR1). The roots were washed thoroughly with tap water and dried at $37^{\circ} \mathrm{C}$ in an incubator, then cut into small pieces and powdered finely before extraction.

\section{Preparation of Plant Extraction}

About $100 \mathrm{~g}$ of the dried powder of the roots of AR was extracted with either $1000 \mathrm{~mL}$ of $95 \%$ ethanol using a Soxhlet apparatus or boiled with water at

Cite this article: Taepongsorat L., Rattana S. Antioxidant Activities of Ethanolic and Aqueous Extracts of Asparagus racemosus Roots. Pharmacogn J. 2018;10(6):1129-32. 
$100^{\circ} \mathrm{C}$ for $10 \mathrm{~min}$. The extracts were concentrated to dryness under a reduce pressure and controlled temperature using an evaporator and a freeze-dryer, respectively.

\section{DPPH radical scavenging assay}

The antioxidant activities of the ethanolic and aqueous extracts of the AR root were determined using a method based on the reduction of the ethanolic solution of color-free radical 1, 1 diphenyl-1-2 picrylhydraxyl $(\mathrm{DPPH}) .^{7-8}$ An ascorbic acid solution was used as a reference standard. A varied dose of each extract (10-1000 ug/mL, dissolved in 10\% DMSO) was added to a volume of $750 \mu \mathrm{L} \mathrm{DPPH}$ in absolute ethanol, incubated at room temperature in the dark for $20 \mathrm{~min}$ and measured for absorbance at $517 \mathrm{~nm}$ using a 96-well plate with microtiter plate reader (BMG LABTECH GmbH, Ortenberg, Germany). The inhibition percentages of the radical scavenging activity of the samples were expressed as follows:

$\%$ inhibition $=[($ A control-A sample $) / A$ control $] \times 100$

The absorbance values of the DPPH solutions without or with a sample added were the control and samples, respectively.

The inhibitory concentration of the sample requires a scavenging activity for the $\mathrm{DPPH}$ radical of $50 \%\left(\mathrm{IC}_{50}\right.$ value) as obtaining from a linear regression analysis of a calibration curve.

\section{ABTS radical scavenging activity}

A decolorization test was performed using the spectrophotometric method of previous studies with a slight modification. ${ }^{9-10}$ A stock solution of ABTS was mixed, $7 \mathrm{mM}$ of ABTS stock solution ( $\mathrm{pH}$ 7.4) with 140 $\mathrm{mM}$ potassium persulfate $\left(\mathrm{K}_{2} \mathrm{~S}_{2} \mathrm{O}_{8}\right)$. Ethanol was used to dilute the ABTS for the working solution. The test concentrations of the standard ascorbic acid and extracts were as previously described for the DPPH assay. The ABTS working solution $(100 \mu \mathrm{L})$ with an equal volume of ethanol served as a control and was incubated for $30 \mathrm{~min}$ at room temperature. The absorbance of each solution was determined at $743 \mathrm{~nm}$ usinga 96-well plate with microtiter plate reader (BMG LABTECH GmbH, Ortenberg, Germany). The percentage of inhibition was expressed as follows:

$\%$ inhibition $=[($ A control-A sample $) / A$ control $] \times 100$

The control was the absorbance of the ABTS solution without a sample. An effective concentration for the sample requires scavenging of the ABTS radical at $50 \%\left(\mathrm{EC}_{50}\right.$ value $)$ and this was obtained by linear regression analysis of a calibration curve plotting \% inhibition versus concentration.

\section{FRAP assay (Ferric reducing antioxidant power)}

The FRAP assay was undertaken with some modification to the method of Benzie and Strain. ${ }^{11}$ The ratio of the $300 \mathrm{mM}$ acetate buffer ( $\mathrm{pH}$ 3.6), $10 \mathrm{mM}$ TPTZ in $40 \mathrm{mM} \mathrm{HCl}$ and $20 \mathrm{mM}$ ferric chloride was 10:1:1 $(\mathrm{v} / \mathrm{v} / \mathrm{v})$, respectively. A total of $30 \mu \mathrm{L}$ of the sample extract was added to $270 \mu \mathrm{L}$ of the FRAP reagent and mixed well. After $30 \mathrm{~min}$ incubation at room temperature, the absorbance values of the samples were subsequently measured at $593 \mathrm{~nm}$ in three replicates using a microplate reader (BMG LABTECH GmbH, Ortenberg, Germany).The antioxidant capacity of the extract was compared with a trolox calibration curve and expressed as $\mu \mathrm{mol}$ Trolox equivalent (TE) per gram of extract.

\section{Determination of total flavonoid contents}

Flavonoid contents were measured by the aluminium chloride colorimetric methodas described by Kim et al. with slight modification. ${ }^{12}$ Fifty milligrams of each AR extract was suspended in $10 \mathrm{~mL}$ of $80 \%$ methanol, sonicated for $15 \mathrm{~min}$ and filtered through Whatman filter paper No.42 (125 mm). Then mixed $0.3 \mathrm{~mL}$ of filtrate, $3.4 \mathrm{~mL}$ of $30 \%$ methanol, 0.15 $\mathrm{mL}$ of $0.5 \mathrm{M} \mathrm{NaNO}_{2}$ and $0.15 \mathrm{~mL}$ of $0.3 \mathrm{M} \mathrm{AlCl}_{3}-6 \mathrm{H}_{2} \mathrm{O}$ in a test tube. Add
$1 \mathrm{~mL}$ of $1 \mathrm{M} \mathrm{NaOH}$ for $5 \mathrm{~min}$, and then the absorbance was measured at $510 \mathrm{~nm}$. A standard calibration curve was constructed using known quercetin concentrations against absorbance. Total flavonoid contents were determined on the basis of absorbance and calculated as mg quercetin equivalent per gram of extract ( $\mathrm{mg} \mathrm{QE} / \mathrm{g}$ powder).

\section{Determination of total phenolic compound}

Total soluble phenolic content in the extracts was determined using the Folin-Ciocalteu method as previously described by Thaipong et al. with a slight modification. ${ }^{13} 10 \%$ Folin-Ciocalteu solution $(400 \mu \mathrm{l})$ was mixed with $200 \mu \mathrm{l}$ of the sample solution $(1.0 \mathrm{mg} / \mathrm{mL})$ in a volumetric flask and incubated at room temperature for $10 \mathrm{~min}$ before being mixed with $0.2 \mathrm{~mL}$ of $7 \% \mathrm{Na}_{2} \mathrm{CO}_{3}$ solution. Finally the mixture was diluted with deionized distilled water and made up to $10 \mathrm{~mL}$ in a volumetric flask. The mixture was kept at room temperature for 2 hours and then had the absorbance measured at $725 \mathrm{~nm}$. The total phenolic compounds in the extract were presented as grams of gallic acid equivalent (GAE) using an equation obtained from the regression line of a standard gallic acid graph: $y=0.2177 x+0.0005, r^{2}=0.999$. Where, $y$ was the absorbance and $x$ was the concentration. Total phenolics were then calculated as mg gallic acid equivalent per gram of extract (mg GAE/g extract).

\section{Statistical analysis}

Results were expressed as means \pm SEM. Statistical analysis was determined using a one-way ANOVA followed by Student's t-tests. P-values $<0.05$ were considered to be statistically significant.

\section{RESULTS}

The percentage yields of the aqueous and the ethanolic extracts of AR were 27.41 and 20.88 , respectively.

\section{DPPH radical scavenging assay}

The antioxidant activity of ascorbic acid by DPPH method was found to be greater than those of the ethanolic and the aqueous AR root extracts (Table 1). There was a significant decrease in the concentration of the $\mathrm{DPPH}$ radical due to the scavenging ability of both extracts. The ethanolic extract had a scavenging activity that was better than that of the aqueous extract.

\section{Table 1: Antioxidant activities of AR root extracts}

\begin{tabular}{|c|c|c|c|}
\hline \multirow[b]{2}{*}{ Herbal extracts } & \multicolumn{3}{|c|}{ Antioxidant activities } \\
\hline & $\begin{array}{c}\text { DPPH } \\
(\mathrm{IC} 50 ; \mu \mathrm{g} / \mathrm{mL})\end{array}$ & $\begin{array}{c}\text { ABTS } \\
\text { (IC50; } \mu \mathrm{g} / \mathrm{mL})\end{array}$ & $\begin{array}{c}\text { FRAP } \\
\text { ( } \mu \text { mol trolox } \\
/ 100 \mathrm{~g} \text { extract })\end{array}$ \\
\hline Water extract & $1121.24 \pm 121.80^{*}$ & $923.31 \pm 8.46^{*}$ & $252.46 \pm 0.44^{*}$ \\
\hline $\begin{array}{l}95 \% \mathrm{EtOH} \\
\text { extract }\end{array}$ & $950.34 \pm 83.02^{*}$ & $247.42 \pm 31.89^{*}$ & $299.74 \pm 5.43^{*}$ \\
\hline L-ascorbic acid & $3.37 \pm 0.02^{*}$ & $7.63 \pm 0.13^{*}$ & - \\
\hline
\end{tabular}

in the same column showed significant differences $(\mathrm{p}<0.05)$

\section{ABTS RADICAL SCAVENGING ACTIVITY}

There was a decrease in the concentration of the ABTS radical due to the scavenging abilities of both extracts (Table 1). The ethanolic extract of the AR roots had a scavenging activity that was better than that of the aqueous extract. 


\section{FRAP assay (Ferric reducing antioxidant power)}

The trolox equivalents in the ethanolic and aqueous extracts of AR roots are shown in Table 1 . The trolox equivalent scavenging ability of the ethanolic extract of the AR roots was significantly greater than that of the aqueous extract of the AR roots.

\section{Determination of total phenolic compounds}

The total phenolic contents in the ethanolic and the aqueous extracts of AR roots are shown in Table 2 . The ethanolic extract had significantly higher total phenolic contents than the aqueous extract.

Table 2: Phenolic and flavonoid contents of AR root extractions.

\begin{tabular}{lll}
\hline $\begin{array}{l}\text { Herbal } \\
\text { extracts }\end{array}$ & $\begin{array}{l}\text { Total phenolic } \\
\text { contents } \\
\text { (mg gallic acid/100 g } \\
\text { extract) }\end{array}$ & $\begin{array}{l}\text { Total flavonoids } \\
\text { (mg Quercetin/100 g extract) }\end{array}$ \\
\hline $\begin{array}{l}\text { Water extract } \\
95 \% \text { EtOH }\end{array}$ & $0.10 \pm 0.01^{*}$ & $0.08 \pm 0.01^{*}$ \\
extract & $4.82 \pm 0.38^{*}$ & $0.48 \pm 0.02^{*}$ \\
\hline
\end{tabular}

in the same column showed significant differences $(p<0.05)$

\section{Determination of total flavonoid contents}

The total flavonoids in the ethanolic and the aqueous extracts of AR roots are shown in Table 2. The ethanolic extract had significantly higher total flavonoids than the aqueous extract of AR roots.

\section{DISCUSSION}

The results of this present study indicated that the plant extracts were moderately free radical scavengers, which could reduce or reverse damage caused by free radicals in the human body. The antioxidant activity of the ethanolic extract of AR roots was better than that from the aqueous extract. The total phenolic contents and total flavonoids in the ethanolic extract were also higher than those in the aqueous extract. This study showed that the scavenging ability, total phenolic compounds and total flavonoid contents of the ethanolic extract were higher than those from the aqueous extract but were four times lower than those reported from a methanolic extract. ${ }^{2}$ The scavenging ability of the aqueous extract in this study was better than the study of Kongkaneramit et al. ${ }^{1}$ The previous study reported that the main components were saponins such as shatvarin, sarsapogenin and kaempferol.

The presence of phenolic compounds is shown mostly via the antioxidant activities of plant sources. Due to their hydroxyl groups, phenols are very important plant constituents with a good scavenging ability. The presence of large quantities of phenolic compounds does not necessarily always correlate with antioxidant effects. ${ }^{6}$ AR has been reported to have antioxidant activity. Methanolic root extracts were found to markedly increase superoxide dismutase, while decreasing lipid peroxidation in rats. ${ }^{14}{ }^{15}$ In addition, AR has recently been shown to contain saponins, steroida ${ }^{16}$ and racemofuran. ${ }^{17}$ The aqueous extract has also been shown to exhibit anantioxidant effect in rat liver and inactivation of superoxide dismutase ${ }^{18}$ and the amelioration of oxidative stress. ${ }^{19}$ The antioxidant activity in terms of mean inhibitory concentrations $\left(\mathrm{IC}_{50}\right)$ of ascorbic acid, ethanolic and aqueous extracts were found to be 3.37, 950.34 and $1121.24 \mu \mathrm{g} / \mathrm{mL}$, respectively, when using the DPPH method. The effective concentration $\left(\mathrm{EC}_{50}\right)$ of a crude ethanol extract of AR was $381.91 \mu \mathrm{g} /$ $\mathrm{mL},{ }^{20} 600 \mu \mathrm{g} / \mathrm{mL} .{ }^{1}$ The methanolic extract of the root of AR was 4158.8 $\mu \mathrm{g} / \mathrm{mL}$ when using butylated hydroxyl toluene as a standard. ${ }^{2}$ The present study showed that both the ethanolic and the aqueous extracts of the roots have moderate antioxidant activities.
Although AR extracts exhibited far less antioxidant activity than ascorbic acid when tested in vitro using the DPPH method, ${ }_{15}{ }_{-}^{16}$ when considering the antioxidant enzyme: superoxide dismutase and ascorbic acid were increased by the effects of AR aqueous and methanolic extracts. ${ }^{1}$

AR extracts contained saponins as the main constituents $(8.83 \%)$, followed by polyphenols (1.69\%), phytosterols $(0.79 \%)$, ascorbic acid $(0.76 \%)$ and flavonoids $(0.47 \%)$, respectively. ${ }^{5}$ These compounds could be responsible for decreased cholesterol levels and increased fecal sterol excretion in hypercholesteremic rats. Phytosterols have been reported to complete and displace cholesterol from intestinal bile acid micelles and decrease cholesterol circulation..$^{21-22}$ Saponins reduced the plasma cholesterol level by interfere with the enterohepatic circulation of bile acids and so making it unavailable for intestinal absorption of cholesterol. ${ }^{23}$ Polyphenolic compounds and phenolic acids, found in plants, have multiple biological effects, including antioxidant activity. ${ }^{24}$ Ascorbic acid shows very strong antioxidative activities. ${ }^{25}$

Our in vitro studies showed that AR has moderate free radical scavenging action. The antioxidant properties of both the ethanolic and the aqueous extracts of AR can be attributed to the presence of ascorbic acid, flavonoids and polyphenols, which in turn may be responsible for its antioxidative effects. ${ }^{2}$

\section{CONCLUSION}

These results have shown high phenolic and flavonoid contents. The ethanolic extract of AR root possessed higher amounts of phenolic and flavonoid contents than the aqueous extract. In conclusion, the antioxidant capacity of the ethanolic extract was higher than the aqueous extract.

\section{ACKNOWLEDGEMENT}

The authors would like to acknowledge the Faculty of Medicine, Mahasakham University, Thailand for providing a financial grant. We are also grateful to the Department of Biology, Faculty of Science, Mahasakham University for providing facilities.

\section{CONFLICT OF INTEREST}

The authors declare no conflict of interest.

\section{REFERENCES}

1. Kongkaneramit $L$, Witoonsardsilp W, Peeungvicha $P$, Ingkaninan $K$, Waranuch N, Sarisuta N. Antioxidant activity and antiapoptotic effect of Asparagus racemosus root extracts in human lung epithelial H460 cells. Exp Ther Med. $2011 ; 2(1): 143-8$

2. Naquvi KJ, Dohare S, Shuaib M. In vitro antioxidant activity Asparagus racemosus root. Int J Biomed Res. 2011;2(4):228-35.

3. Joshi JDS. Chemistry of Ayurvedic crude drugs: Part VIII: Shatavari 2. Structure elucidation of bioactive shatavarin I and other glycosides. Indian J Chem Section B Organ Chem. 1988;27(1):12-6.

4. Hayes PY, Jahidin AH, Lehmann R, Penman K, Kitching W, De Voss JJ. Structure revision of shatavarins I and IV, the major component from the roots of Asparagus racemosus. Terahedron Letter. 2006;47:6965-9.

5. Visavadiya N, Narasimhacharya RL. Asparagus Root regulates cholesterol metabolism and improves antioxidant status in hypercholesteremic rats. eCAM. 2009;6(2):219-26.

6. Bopana N, Saxena S. Asparagus racemosus-Ethnopharmacological evaluation and conservation needs. J Ethnopharmacol. 2007;110(1):1-15.

7. Rattna S, Katisart T, Sungthong B, Butiman C. Acute and sub-acute toxicities of Thai Silkworm Powder (Bombyx mori Linn.) from three races in male Wistar rats and in vitro antioxidant activities. Pharmacog J. 2017;9(4):541-5.

8. Zhang WW, Duan XJ, Huang HL, Zhang Y, Wang BG. Evaluation of 28 marine algae from the Qingdao coat for antioxidative capacity and determination of antioxidant efficiency and total phenolic content of fractions derived from Symphyocladia latiuscula (Rhodomelaceae). J Appl Phycol. 2007;19(2):97-108.

9. Joshi MB, Saatarkar A. Phytochemical investigation of the roots of Grewia microcos Linn. J Chem Pharm Res. 2013;5(7):80-7.

10. Rahim AA, Rocca E, Steinmetz J, Kassim MJ, Ibrahim MS, Osman H. Antioxidant activities of mangrove Rhizophora apiculate bark extract. Food Chem. 
2008;107(1):200-7

11. Benzie IFF, Strain JJ. Ferric reducing/antioxidant power assay: direct measure of total antioxidant activity of biological fluids and modified version for simultaneous measurement of total antioxidant power and ascorbic acid concentration. Method Enzymol. 1999;299:15-27.

12. Kim DO, Jeong SW, Lee CY. Antioxidant capacity of phenolic phytochemicals from various cultivars of plums. Food Chem. 2003;81(3):321-6.

13. Thaipong K, Boonprokob U, Crosby K, Cisneros-Zevallos L, Byrne DH. Comparison of ABTS, DPPH, FRAP, and ORAC assays for estimating antioxidant activity from guava fruit extracts. J Food Comp Anal. 2006;19(6-7):669-75.

14. Bhatnagar M, Sisodia SS, Bhatnagar R. Antiulcer and antioxidant activity of Asparagus racemosus Willd and Withania somnifera Dunal in rats. Ann NY Acad Sci. 2005;1056(1):261-78.

15. Sairam K, Priyambada S, Aryya NC, Goel RK. Gastroduodenal ulcer protective activity of Asparagus racemosus: an experimental, biochemical and histological study. J Ethnopharmacol. 2003;86(1):1-10.

16. Hayes PY, Jahidin AH, Lehmann R, Penman K, Kitching W, De Voss JJ. Steroidal saponins from the roots of Asparagus racemosus. Phytochemistry. 2008;69(3):796-804.

17. Wiboonpun N, Phuwapraisirisan P, Tip-pyang S. Identification of antioxidant compound from Asparagus racemosus. Phytother Res. 2004;18(9):771-3.

18. Kamat JP, Boloor KK, Devasagayam TPA, Venkatachalam SR. Antioxidant properties of Asparagus racemosus against damage induced by $\gamma$-radiation in rat liver mitochondria. J Ethnopharmacol. 2000;71(3):425-35.

19. Agrawal A, Sharma M, Rai SK, Singh B, Tiwari M, Chandra R. The effect of the aqueous extract of the roots of Asparagus racemosus on hepatocarcinogenesis initiated by diethylnitrosamine. Phytother Res. 2008;22(9):1175-82.

20. Potduang B, Meeploy M, Giwanon R, Benmart Y, Kaewduang M, Supatanakul W. Biological activities of Asparagus racemosus. Afr J Tradit Complement Altern Med. 2008;5(3):230-7.

21. Quilez J, Garcia-Lorda P, Salas-Salvado J. Potential uses and benefits of phytosterols in diet: present situation and future directions. Clin Nutr. 2003;22(4):343 51.

22. Ikeda I, Sugano M. Inhibition of cholesterol absorption by plant sterols for mass intervention. Curr Opin Lipidol. 1998;9(6):527-31.

23. Harwood HJ,Chandler CE, Pellarin LD, Bangerter FW, Wilkins RW, Long CA, et al. Pharmacologic consequences of cholesterol absorption inhibition: alteration in cholesterol metabolism and reduction in plasma cholesterol concentration induced by the synthetic saponin $\beta$-tigogenin cellobioside (CP-88818;tiqueside). J Lipid Res. 1993;34(3):377-95.

24. Paramapojn S, Gritsanapan W. Free radical scavenging activity determination and quantitative analysis of curcuminoids in Curcumaa zedoaria rhizome ex tracts by HPLC method. Curr Sci. 2009;97(7):1069-73.

25. Dekkers JC, Doornen LJP, Han CG. The role of Antioxidant Vitamins and Enzymes in the Prevention of Exercise-Induced Muscle Damage. Sports Med. 1996;21(3):213-38.

Cite this article: Taepongsorat L., Rattana S. Antioxidant Activities of Ethanolic and Aqueous Extracts of Asparagus racemosus

Roots. Pharmacogn J. 2018;10(6):1129-32. 